\title{
The Critical Thinking Skills Profile of Preservice Biology Teachers in Animal Physiology
}

\author{
Astuti Muh. Amin \\ Graduate Student, Department of Biology Education, \\ State University of Malang, Indonesia \\ astutiamin@gmail.com
}

\author{
Aloysius Duran Corebima \\ Biology Department, \\ State University of Malang, Indonesia \\ duran.corebima.fmipa@um.ac.id
}

\author{
Siti Zubaidah \\ Biology Department, \\ State University of Malang, Indonesia \\ sitizubaidahbioum@gmail.com \\ Susriyati Mahanal \\ Biology Department, \\ State University of Malang, Indonesia \\ susriyati.mahanal.fmipa@um.ac.id
}

\begin{abstract}
In facing challenges in the $21^{\text {st }}$ century, the university students need to empower their critical thinking skills. Critical thinking skills can improve students' verbal and analytic skills through helping them express useful ideas to increase their knowledge. This study, therefore, attempted to outline the profile of pre-service biology teachers' critical thinking skills in Animal Physiology. The design of this study was descriptive quantitative. Data was collected using a questionnaire and a test to examine the students' critical thinking skills. The sample of this research consisted of 139 university students from UIN Alauddin Makassar, STKIP PI Makassar, UPRI Makassar, and STKIP Yapim Maros. Research findings suggest that (1) the students' topic understanding and critical thinking skills were still low; and (2) the students' average test score was 2.11 (which means that the students' critical thinking skills were not well developed). These results, therefore, serve as a preliminary analysis result of problems faced in biology learning. Furthermore, they also provide an insight for teachers to improve the quality of their biology instruction.
\end{abstract}

Keywords: pre-service biology teachers, animal physiology, critical thinking skills profile

\section{INTRODUCTION}

The system of thinking is a competency required to face the $21^{\text {st }}$ challenges [1]. There are numerous definitions and benefits of critical thinking have been suggested by the experts. Critical thinking skills are reflective rational thinking which is focused to decide what to do and what to believe [2]. Someone who thinks critically will be able to ask appropriate questions, associate relevant information effectively and efficiently, organize information creatively and rationally, and make a consistent conclusion. Define critical thinking as an ability that an individual has to provide solution to his/her problems [3]. To be able to find proper solutions in learning, an individual is required to train and develop some abilities. They include the ability to analyze, synthesize, evaluate, generalize, compare, deduce, classify, draw a conclusion from information collected as well as make a decision.

Ideally, the development of critical thinking skills goes side by side with the improvement of knowledge and science application in daily life [4]. Cognitive skill constitutes the core of critical thinking skill [5]. According to [6], developed critical thinking skill can help someone to discover truth, think differently (open and tolerant towards new ideas), analyze problems effectively, think systematically and independently.

Promoting students' critical thinking skill is necessary since it can increase their verbal and analytic skill. Students' critical thinking skill can be trained by assisting them to be able to express useful ideas to increase understanding. Besides, critical thinking skill also plays an important role in self-reflection which means to help students discover truth and values reflection and as a result help them to be able to make their own decision. Learners who possess critical thinking skills construct knowledge which is favorable for their life; thereby, they are able to improve their motivation in solving issues faced every day [7].

A study conducted by [8] found a positive correlation between self cognitive awareness and critical thinking skills. Pre-service teachers are expected to have good attitude towards stimulating and promoting a thinker who has an ability to interpret, investigate, and inquire critically. Learning environment should support students' interaction and communication which are free from anxiety and stress. It aims to encourage students to find a solution to every problems that arise, evaluate arguments, predict consequences [9], evaluate the pros and cons before making a decision, and make accurate assessment by critically discriminating some alternatives [10].

Critical thinking is associated with constructivism, education, and leadership. Constructivism helps an individual to understand how to grow as an adult, learn in an education system, and finally make a decision as a leader. Leadership is built on the basis of knowledge and experiences as an integration of critical thinking in a constructivism framework [11]. Therefore, critical thinking ability can be used by students to carefully examine others opinions based on scientific justification, and make an appropriate [12].

An observation to learning conducted by [13] shows that there are many students unable to solve problems related to their everyday lives. It occurred as a negative impact brought from a set of learning activities which do not provide an environment in which students learn to solve their problems. The explanation above shows that it is necessary to conduct a preliminary analysis related to students critical 
thinking skill. This study, therefore, aimed to describe the critical thinking skills profile of pre-service biology teachers in Animal Physiology. These results, therefore, serve as a preliminary analysis result of problems faced in biology learning. Furthermore, they also provide an insight for teachers to improve the quality of their biology instruction.

\section{METHODS}

This study employed a descriptive quantitative method using a questionnaire and a test of critical thinking skill. The participants of the research were 139 pre-service biology teachers from STKIP Pembangunan Indonesia Makassar, UIN Alauddin Makassar, Universitas Pejuang Republik Indonesia (UPRI) Makassar, STKIP Yapim Maros. This study was conducted from December 2015 until June 2016.

The test consisted of essay questions which were developed according to [14] revised version of Bloom's taxonomy. This test examined students' mastery of materials covered in Animal Physiology course. The answers indicated students' ability in applying (C3), analyzing (C4), evaluating (C5), and creating (C6). The score was then conversed using the critical thinking scoring rubric developed by [12]. The scoring rubric was adapted from Illinois Critical Thinking Essay Test and Guidelines for Scoring Illinois Critical Thinking Essay Test. It consists of five scales (0-5). The components of the scoring rubric cover (1) focus, (2) supporting reasons and reasoning, (3) organization, (4) conventions, (5) integration. Data of the students' average score was categorized into not well developed (1-3), and well developed (4-5).

\section{Result}

\section{RESULT AND DISCUSSION}

Table 1 depicts the results of the questionnaire distributed to elicit pre-service biology teachers' perception on critical thinking skill. Based on the information in Table 1, it can be concluded that the students' understanding and promotion of critical thinking skills were very low. Meanwhile, the recapitulation of the results of the essay test is presented in Table 2.

Table 1

Recapitulation of the Results of the Questionnaire

\begin{tabular}{|c|c|c|c|c|c|c|}
\hline \multirow[b]{2}{*}{ No } & \multirow[b]{2}{*}{ Statements } & \multicolumn{5}{|c|}{ Universities/Colleges } \\
\hline & & $\begin{array}{c}\text { STKIP Pembangunan } \\
\text { Indonesia (PI) Makassar (\%) } \\
\end{array}$ & $\begin{array}{l}\text { UIN Alauddin } \\
\text { Makassar }(\%) \\
\end{array}$ & $\begin{array}{c}\text { UPRI Makassar } \\
(\%)\end{array}$ & $\begin{array}{c}\text { STKIP Yapim } \\
\text { Maros (\%) }\end{array}$ & $\begin{array}{c}\text { Average Score } \\
(\%)\end{array}$ \\
\hline 1 & $\begin{array}{l}\text { Able to provide critical and logic explanation } \\
\text { of Animal Physiology. }\end{array}$ & 26.32 & 48.48 & 23.68 & 36.36 & 33.71 \\
\hline 2 & $\begin{array}{l}\text { Find some difficulties in discussing the results } \\
\text { of practicum observation. }\end{array}$ & 84.21 & 75.76 & 73.68 & 78.79 & 78.11 \\
\hline 3 & $\begin{array}{l}\text { Find some difficulties in writing the report of } \\
\text { Animal Physiology practicum }\end{array}$ & 86.84 & 84.85 & 84.21 & 87.88 & 85.94 \\
\hline 4 & $\begin{array}{l}\text { Recognize the indicators of critical thinking } \\
\text { skills. }\end{array}$ & 10.53 & 24.24 & 18.42 & 21.21 & 18.60 \\
\hline 5 & $\begin{array}{l}\text { Recognize the importance of critical thinking } \\
\text { skills. }\end{array}$ & 73.68 & 66.67 & 76.68 & 69.70 & 71.68 \\
\hline 6 & $\begin{array}{l}\text { Recognize the purpose of promoting critical } \\
\text { thinking skills in the classroom. }\end{array}$ & 26.32 & 45.45 & 57.89 & 39.39 & 42.26 \\
\hline 7 & $\begin{array}{l}\text { Have been trained to improve interpretation } \\
\text { skill. }\end{array}$ & 36.84 & 33.33 & 34.21 & 36.36 & 35.18 \\
\hline 8 & Have been trained to improve analysis skill. & 68.42 & 54.55 & 60.53 & 57.58 & 60.27 \\
\hline 9 & $\begin{array}{l}\text { Have been trained to improve making an } \\
\text { inference skill. }\end{array}$ & 31.58 & 51.52 & 44.74 & 45.45 & 43.33 \\
\hline 10 & Have been trained to improve evaluation skill. & 57.89 & 57.58 & 47.37 & 51.52 & 53.59 \\
\hline 11 & $\begin{array}{l}\text { Have been trained to improve explaination } \\
\text { skill. }\end{array}$ & 50.00 & 48.48 & 55.26 & 45.45 & 49.79 \\
\hline 12 & $\begin{array}{l}\text { Have been trained to improve self-regulation } \\
\text { skill. }\end{array}$ & 18.42 & 27.27 & 26.32 & 21.21 & 23.31 \\
\hline
\end{tabular}

Table 2

Description of Pre-service Biology Teachers' Critical Thinking Skills Measured by an Essay Test

\begin{tabular}{|c|c|c|c|c|c|}
\hline & \multicolumn{4}{|c|}{ Universities/Colleges } & \multirow[b]{2}{*}{ Average Score } \\
\hline & $\begin{array}{c}\text { STKIP Pembangunan Indonesia } \\
\text { (PI) Makassar (\%) }\end{array}$ & $\begin{array}{l}\text { UIN Alauddin } \\
\text { Makassar (\%) }\end{array}$ & UPRI Makassar (\%) & $\begin{array}{l}\text { STKIP Yapim } \\
\text { Maros }(\%)\end{array}$ & \\
\hline Highest score & 54 & 70 & 62 & 74 & 65 \\
\hline Lowest score & 16 & 22 & 22 & 22 & 20.5 \\
\hline Score range & 38 & 48 & 40 & 52 & 44.5 \\
\hline Total Average Score & 29.64 & 51.04 & 46.40 & 41.58 & 42.16 \\
\hline Average Score per item & 1.48 & 2.55 & 2.32 & 2.08 & 2.11 \\
\hline
\end{tabular}

Table 3

Categorization of Pre-service Biology Teachers' Test Score

\begin{tabular}{lcc|c|cc}
\hline \multicolumn{1}{c}{ Category } & $\begin{array}{c}\text { Range of } \\
\text { Average } \\
\text { Score }\end{array}$ & $\begin{array}{c}\text { STKIP Pembangunan } \\
\text { Indonesia (PI) Makassar } \\
(\%)\end{array}$ & $\begin{array}{c}\text { UIN Alauddin } \\
\text { Makassar (\%) }\end{array}$ & $\begin{array}{c}\text { UPRI } \\
\text { Makassar (\%) }\end{array}$ & $\begin{array}{c}\text { STKIP } \\
\text { Yapim } \\
\text { Maros (\%) }\end{array}$ \\
\hline Not well-developed & $1-3$ & $100 \%$ & $100 \%$ & $100 \%$ & $100 \%$ \\
Well- developed & $4-5$ & $0 \%$ & $0 \%$ & $0 \%$ & $0 \%$ \\
\hline
\end{tabular}


Table 2 indicates that the average score of the students' critical thinking skill test is 2,11 . The categorization of the students' score can be seen in Table 3. Based on Table 3, it can be found out that $100 \%$ of the students from STKIP Pembangunan Indonesia (PI) Makassar, UIN Alauddin Makassar, UPRI Makassar, STKIP Yapim Maros had unwelldeveloped critical thinking skills.

\section{Discussion}

The results of the questionnaire and the essay test indicate that the students' critical thinking skills were still low. It has impacted the activity and the independence of the pre-service biology teachers, especially in Animal Physiology. Around 78,11\% of the students faced difficulties in organizing a discussion based on the practicum observation result. Besides, they also found some activities problematic such as interpreting, analyzing, and connecting the practicum results with the theories. According to [15], interpretation skill is the ability to understand and define a situation, experience, event, data, and decision. Meanwhile, analysis skill is to be able to identify the connection between statements, questions, concepts, descriptions, and models used to reflect thoughts, perceptions, information, and opinions. The two abilities belong to the critical thinking skills indicators.

Two main factors that support the development of the university students' critical thinking skills are lecturers' activities and students' activities [16] Lecturers' participation in learning should be limited as a facilitator and students' learning assistant. It means that the lecturers are only required to stimulate students' thinking and provide a situation for the students to analyze an authentic problem through the application of concepts and facts. This learning condition is expected to make the students able to assign meanings to problems and events that occurred surrounding them. It, therefore, reflects the students' critical thinking skills [17].

Based on the results of the survey, it can be found out that 58,13\% of the lecturers in Makassar used lecture, $18,47 \%$ of them used discussion, $21,37 \%$ used question and answer technique, $1,89 \%$ used demonstration, $13,96 \%$ gave assignment, $11,72 \%$ asked students to do an experiment, and 2,63\% used other learning methods in the biology classrooms. It indicates that lecture still dominated biology learning. As a result, the students were passive since they were not actively engaged in learning. This learning condition also impacted the students' thinking level which cannot surpass the remembering stage [18].

An observation conducted in STKIP Persada Khatulistiwa Sintang showed that students' low critical thinking skills resulted from domination of lecturers' activities. The lecturers did not provide the students with an opportunity to express their ideas/opinions so that the students were not used to making arguments in the classroom [19]. In addition to that, [20] have proven that students' low critical thinking skills are caused by traditional learning strategies that are still applied in the classroom. Similarly, [21] found out that learning in the university was still dominated by lecturers' presentation and students' note-taking activities. This learning pattern, therefore, has led to low students' effectiveness and negatively impacted some aspects of learning including (1) students' analysis skill, (2) students' problem solving skill, and (3) students' ability in evaluating learning holistically. Furthermore, [22] explains that giving lecture and explaining concepts are not enough to improve students' critical thinking. The students should be trained how to practice their skills through active learning.

In the $21^{\text {st }}$ century, one of important aspects to prove an effective learning is to examine lecturers' effectiveness in improving students' critical thinking skills [23]. Critical thinking skills cover many skills including carefully listening to and reading information, investigating and finding hidden assumptions, and predicting consequences of a statement [24]. Students' critical thinking skills in biology learning can be improved through a contextual learning. The students, in this case, are perceived as active actors who actively seek for various learning sources, conduct an investigation, and solve problems [25].

Critical thinking is thinking power that is developed by the university students as a character. Every student is unique because they possess different academic ability and thinking skills [26]. Critical thinking skills are important for the students because they assist the students in being rational and making the best decision in their lives. Students who have critical thinking skills will keep being reflective before making a decision [15].

Thinking skills are the core of learning. They make everything possible. Humans can learn without thinking, but through experiences for example (learning by rote and learning by accident). However, humans can only manage to learn to think. Equipping students with thinking skills means helping them to survive in the future [27]. According to [24]. students are particularly required to thinking critically in learning and practicing their knowledge for two reasons. The first reason is because they constitute a part of the scientific society. This society works for the advancement of science and humans well-being. Science can develop because people keep asking and doubting existing theories and inventions. The other reason is because university students need to be professional, either before or after they graduate. As a professional, university students are required to improve the society welfare. To be able to see what is wrong with the society, they need to be open to changes. Therefore, they need to improve their critical thinking skills which can also help them improve their ability in designing conducive learning and creating good learning atmosphere.

\section{CONCLUSION AND SUGGESTIONS}

Research findings suggest that (1) the students' topic understanding and critical thinking skills were still low; (2) the students' average test score was 2,11 (which means that the students' critical thinking skills 
were not well developed). These results, therefore, serve as a preliminary analysis result of problems faced in biology learning. Furthermore, they also provide an insight for teachers to improve the quality of their biology instruction. This research can also become a reference for future researchers who wish to further investigate university students' critical thinking skills. The attempts could be in the form of implementing active and constructive learning models, strategies, or methods.

\section{ACKNOWLDGEMENT}

We would like to thank Ibu Jamilah, S.Si., M.Si as the Head of Biology Department of UIN Makassar; Ibu Etty Rosmiati S.Pd., M.Pd as the Head of Mathematics and Natural Sciences Department of FKIP UPRI Makassar; Ibu Eka Aprilia, M.Pd as the Head of Biology Education Program of STKIP PI Makassar; and the Head of Biology Education Program of STKIP Yapim Makassar for facilitating meetings with Biology lecturers. Our gratitude also goes to Asrijal, M.Pd and his team who have assisted us in data recapitulation.

\section{REFERENCES}

[1] Alghamdi, A. K. H., and Hassan, N. A. S. 2016. The Effectiveness of the Mawhiba Program for the Development of Critical Thinking Skill among Gifted Female Students at Secondary Levels. British Journal of Education Society \& Behavioural Science, 14(2), 113.

[2] Amin, A. M., Corebima, A. D., Zubaidah, S., Mahanal, S. 2016 Identifikasi Kemampuan Bertanya dan Berpendapat Calon Guru Biologi pada Mata Kuliah Fisiologi Hewan. Proceeding National Seminar on Pendidikan Biologi, Jember University, 12 November.

[3] Anderson, J. A. 2003 Critical Thinking Across the Disciplines. New York: College of Technology New York.

[4] Anderson, L. W., and Krathwohl, D. R. 2001 A Taxonomy for Learning Teaching and Assessing a Revision of Bloom's Taxonomy of Educational Objectives. New York: Addison Wesley, Longman Inc.

[5] Ariyati, 2015. Pembelajaran Berbasis Masalah untuk Mengembangkan kemampuan Berpikir Kritis Mahasiswa. Proceeding National Seminar on Pendidikan Biologi Prodi Pendidikan Biologi Universitas Muhammadiyah Malang, 21 March.

[6] Barzdziukiene, R. 2006. Developing Critical Thinking through Cooperative Learning Jounal Kalby Studijos Lithuanian University of Agriculture. Educational Philosophy and Theory, 44(2), 1-13.

[7] Bustami, Y., dan Corebima, A. D., 2017. The Effect of JiRQA Learning Strategy on Critical Thinking Skills of Multiethnic Studens in Higher Education Indonesia. International Journal of Humanities Social and Education (IJHSSE), 4(3), 13-22.

[8] Dwijananti, P., and Yulianti, D. 2010. Pengembangan Kemampuan Berpikir Kritis Mahasiswa melalui Pembelajaran Problem Based Instruction pada Mata Kuliah Fisika Lingkungan. Jurnal Pendidikan Fisika Indonesia, 6, 108-114.

[9] Ennis, R. H. 1991. Critical Thinking: A Streamlined Conception. Teaching Philosophy, 14(1), 5-24.

[10] Facione, P. A. 2010. Critical Thiking: What it is and Why it Counts. California: California Academic Press.
Retrieved December 9, 2016, from http://www.insightassesment.com/pdf_files/what $\% 26 \mathrm{w}$ hy2006.pdf.

[11] Fisher, A. 2009. Berpikir Kritis: Sebuah Pengantar. Jakarta: Penerbit Erlangga.

[12] Flores, Kevin, L., Gina, S. M., Marl, E., Burbach, Courtney, E. Q., and Heath, H. 2012. Deficient Critical Thinking Skills among Collage Graduates: Implication for Leadership. Educational Philosophy and Theory, 44(2), 212-229.

[13] Hasanuddin, and Mulyadi. 2012. Meningkatkan Kemampuan Berpikir Kritis Mahasiswa melalui Strategi RQA. Proceeding National Seminar FKIP Universitas Sebelas Maret Solo, 17 April.

[14] Hasruddin, Nasution, M. Y., and Rezeqi, S. 2015. Aplication of Contextual Learning to Improve Critical Thinking Ability of Students in Biology Teaching and Learning Strategies Class. International Journal of Learning and Edcation Research, 11(3), 109-116.

[15] Karyana, N. 2013. Meningkatkan Kemampuan Berpikir Kritis Melalui Penggunaan Metode Studi Kasus. Bandung: Widyaiswara LPMP Jawa Barat.

[16] Krulik, S., and Rudnick, J. A. 1996. The New Sourcebook for Teaching Reasoning and Problem Solving in Yunior and Senior High School. Boston: Allyn and Bacon.

[17] Lai, E. R., and Viering, M. 2012. Assesing 21st Century Skill: Integrating Research Findings National Council on Measurement in Education. Vancouver B.C: Pearson.

[18] Moore, B. N., and Parker, R. 1986. Critical Thinking. Los Angeles: Mayfield.

[19] National Research Council (NRC). 2012. Assessing 21st Century Skills: Summary of a Workshop. In Koenig, J. A., (Eds)., Rapporteur Committee on the Assessment of $21^{\text {st }}$ Century Skills, Board on Testing and Assessment, Division of Behavioral and Social Sciences and Education. Washington DC: The National Academies Press.

[20] Palennari, M. 2012. Potensi Integrasi Problem Based Learning dengan Pembelajaran Kooperatif Jigsaw dengan Meningkatkan Keterampilan Berpikir Kritis Mahasiswa. Jurnal Bionature, 13(1), 1-9.

[21] Rodzalan, S. A., and Saat, M. M. 2015. The Perception of Critical Thinking and Problem Solving Skill among Malaysian Undergraduate Students. Procedia-Social and Behavorial Sciences, 172, 725-732.

[22] Semerci C and Elaldi, S. 2014. The Roles a Metacognitive Beliefs in Developing Critical Thinking Skills. Bartin University Journal of Faculty of Education, 3(2), 317-333.

[23] Sulistyowati, R. 2015. Meningkatkan Kemampuan Berpikir Kritis Mahasiswa pada Mata Kuliah Salesmanship melalui Metode Pemberian Tugas. Proceeding National Seminar Biology, 9 Mei.

[24] Tanjungsari, R., and Hadiprajitno, P. B. 2012. Analisis Pengaruh Variabel Kontijensi Tugas Teknologi Individual dan Lingkungan terhadp Pemanfaatan Internet Sebagai Sarana Pendidikan (Survei pada Mahasiswa Jurusan Akuntansi Fakultas Ekonomika dan Bisnis Universitas Diponegoro). Dissertation. Semarang: University of Diponegoro.

[25] Widiyowati, I. I. 2015. Hubungan Kemampuan Berpikir Kritis dengan Respon mahasiswa terhadap Penggunaan Model Pembelajaran Advance Organizer pada Materi Larutan Penyangga. Pancaran, 4(1), 89104.

[26] Yen, T. S., and Halili, S. H. 2015. Effective Teaching of Higer-Order Thinking (HOT) in Education The 
Online Journal of Distance Education and e-Learning, 3(2), 41-47.

[27] Zubaidah, S., Corebima, A. D., and Mistianah. 2015. Asesmen Berpikir Kritis Tes Essay. Symposium on Biologi Education University of Ahmad Dahlan, Yogyakarta. 